Syntax Literate: Jurnal Ilmiah Indonesia p-ISSN: 2541-0849

e-ISSN: 2548-1398

Vol. 6, No. 12, Desember 2021

\title{
PERLINDUNGAN KONSUMEN TERKAIT IKLAN YANG MENYESATKAN
}

\section{Tangkas Hadi Perwira, Atik Winanti}

Fakultas Hukum, Universitas Pembangunan Nasional (UPN) Veteran Jakarta, Indonesia Email: tangkash@gmail.com

\begin{abstract}
Abstrak
Saat ini banyak sekali marketing yang memanipulasi iklan suatu produk demi meningkatkan penjualan. Maraknya iklan penipuan ini membuat masyarakat mudah tertipu. Penelitian ini bertujuan untuk mengedukasi masyarakat terkait iklan yang menyesatkan dan kaitannya terhadap hukum perlindungan konsumen karena masih banyaknya masyarakat yang sulit untuk membedakan produk konsumen yang benar-benar sesuai dengan iklan yang tertera. Dari penjelasan diatas maka Masalah yang akan di bahas adalah bagaimana tanggung jawab pelaku usaha terhadap konsumen karena iklan yang menyesatkan? Metode penelitian ini menggunakan penelitian yuridis normatif dengan pendekatan konseptual, pendekatan ini berdasarkan pada doktrin hukum serta perundang-undangan, selain itu juga di kaji dengan studi kasus (Case Study) berkaitan dengan materi yang di kaji. Indonesia merupakan Negara yang berlandaskan pada norma hukum, Undang-undang dan Konstitusional. Pembuatan iklan telah di atur dalam Undang - Undang nomor 24 tahun 1997 tentang penyiaran dan Undang - Undang nomor 8 tahun 1999 tentang perlindungan konsumen. Hasil dari kajian ini berupa hak perlindungan konsumen, serta fakta yang memuat hak tersebut yang berupa pasal hukum dan peraturan hukum tersebut. Penulis sangat berharap agar dapat berkontribusi dalam permasalahan yang sudah terjadi sangat lama di masyarakat di Indonesia. Di era globalissasi seperti sekarng banyak sekali informasi yang menyesatkan terkait produk yang di gunakan oleh masyarakat.
\end{abstract}

Kata Kunci: hukum perlindungan konsumen; undang-undang perlindungan konsumen; manipulasi iklan

\section{Abstract}

The title of this thesis is Consumer Protection Against Misleading Advertising, a problem that is examined in this journal regarding consumer protection against advertisements whose use is not in accordance with the characteristics of products that are often consumed by the public. Currently, a lot of marketers manipulate the advertisement of a product in order to increase sales. The rise of fraudulent advertising has made the public gullible. Based on this problem, the author makes this paper which aims to educate the public regarding misleading advertising and its relation to consumer protection laws because there are still many people who find it difficult to distinguish consumer products that actually correspond to the advertisements listed. Indonesia is a country based on legal, constitutional and constitutional norms. The making of advertisements has been regulated in Law

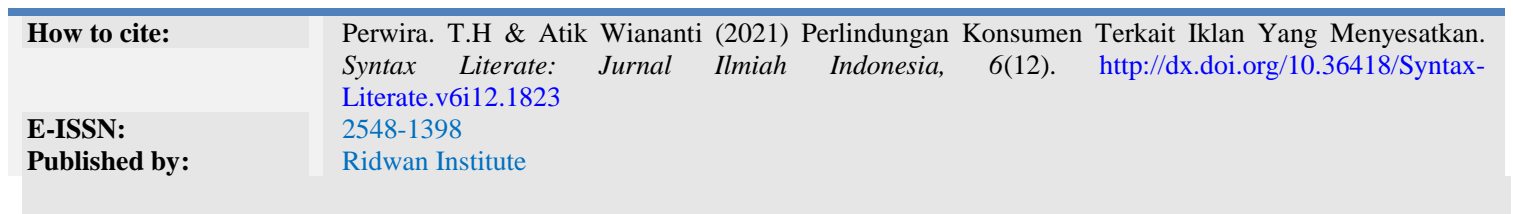


number 24 of 1997 concerning broadcasting and Law number 8 of 1999 concerning consumer protection. This research method uses normative research with a conceptual approach, this approach is based on legal doctrine and legislation, besides that it is also examined with case studies related to the material being studied. The results of this study are in the form of consumer protection rights, as well as facts that contain these rights in the form of legal articles and legal regulations.

Keywords: consumer protection law; consumer protection act; advertising manipulation

Received: 2021-11-20; Accepted: 2021-12-05; Published: 2021-12-20

\section{Pendahuluan}

Iklan merupakan salah satu media yang sering dipakai untuk memasarkan suatu produk baik itu secara online maupun melalui media cetak tertulis seperti majalah ataupun koran (Firmansyah, 2020). Iklan begitu penting perannya sebagai media promosi untuk meningkatkan penjualan produk, dan agar konsumen mengenali produk pelaku usaha bagi perekonomian Indonesia. Indonesia merupakan Negara hukum yang beracuan pada undang - undang dasar 1945 .

Di zaman yang semakin canggih seperti sekarang ini banyak media yang berlomba-lomba memasarkan produk melalui iklan. Periklanan tidak dapat di pisahkan dalam perdagangan global seperti sekarang ini. Tanpa iklan perekonomian tidak akan di kenal serta tidak dapat berjalan lancar. Dalam menyampaikan informasi suatu usaha harus jelas, sesuai fakta, dan dapat di pertanggungjawabkan kepada konsumen hal ini di berlaku bagi pengusaha sehingga tidak membuat pelaku konsumen merasa di rugikan terkait dengan produk tersebut. Iklan yang baik haruslah memuat informasi yang jujur dan bermanfaat bagi konsumen (Sidabalok, 2006).

Tujuan dalam pembangunan nasional adalah mewujudkan suatu keadilan yang makmur dan kesejahteraan bagi rakyat secara adil dan merata baik secara materiil maupun secara spiritual yang berasaskan pada pancasila dan Undang - Undang dasar 1945 (Purhayati, 2020). Diera globalisasi seperti sekarang pertumbuhan ekonomi berlangsung sangat cepat dan lebih modern karena diiringi dengan arus media yang lebih mutakhir. Sehingga mampu menghasilkan produk yang dapat mensejahterakan masyarakat dan mampu mendapatkan kepastian konsumen akan barang yang di produksi untuk masyarakat, tanpa merugikan masyarakat. Sebagai sarana pemasaran, periklanan merupakan media yang penting bagi pembangunan ekonomi di Indonesia, periklanan merupakan media komunikasi yang vital bagi pembangunan usaha di Indonesia yang bermanfaat untuk menunjang pembangunan (Gunawan Widjaja \& Ahmad Yani, 2000).

Menurut Undang - undang nomor 8 tahun 1999 tentang perlindungan konsumen dalam ketentuan umum pasal 1 ayat 6 menyebutkan; promosi adalah kegiatan pengenalan atau penyebarluasan informasi suatu barang dan/atau jasa untuk menarik minat beli konsumen terhadap barang dan/atau jasa yang akan dan sedang 
diperdagangkan (Purhayati, 2020). Periklanan di era globalisasi sekarang dapat di temukan melalui media online, cetak, dan elektronik. Dalam pemasarannya terdapat asas- asas dalam periklanan, sebagai berikut (Simatupang, 2004);

a. Iklan harus jujur, bertanggung jawab, dan tidak bertentangan dengan hokum yang berlaku;

b. Iklan tidak boleh menyinggung perasaan dan merendahkan martabat, Negara, agama, dan adat budaya, hokum dan golongan tertentu;

c. Iklan harus di jiwai oleh asas persaingan yang sehat.

antara adalah konsumen yang menggunakan suatu produk sebagai bagian dari proses produksi suatu produk lainnya. Pengertian Konsumen dalam Undangundang ini adalah konsumen akhir

Dalam jurnal ini akan melampirkan studi kasus Nisan Juke, serta kaitan peristiwa tersebut dengan undang - undang perlindungan konsumen. Kasus Nissan juke terjadi pada bulan maret tahun 2012 lalu yang mengakibatkan seorang remaja wanita meninggal dunia akibat kecelakaan tunggal yang terjadi di daerah jalan sudirman Jakarta.

Tujuan dari penelitian mengenai iklan yang menyesatkan yaitu untuk menyadarkan kepada pembaca dan/atau masyarakat tentang penyalah gunaan iklan, menanggapi iklan yang tidak sesuai dengan produk, bahaya dari penyalahgunaan iklan bagi perlindungan konsumen.

\section{Metode Penelitian}

Dalam melaksanakan pendekatan permasalahan yang berhubungan dengan topik penelitian ini, digunakan metode pendekatan yuridis normatif, penelitian ini dilakukan dengan cara meneliti bahan pustaka atau bahan sekunder belaka, penelitian ini mengacu pada persoalan- persoalan yang menyangkut pada sinkronisasi peraturan daerah dengan Hak Asasi Manusia (Soerjono Soekanto, 2019). Pada metode penelitian berdasarkan teori hukum yang terkait.

\section{A. Pendekatan yang digunakan}

Pendekatan yang digunakan oleh penulis ini menggunakan pendekatan perundang - undangan (statue approach) yaitu menelaah semua peraturan perundangundangan dan regulasi yang bersangkut paut dengan masalah hukum yang di tangani. Pendekatan kasus (Case Approach) dilakukan dengan cara melakukan penelaahan terhadap kasus peralihan hak yang melawan hukum (Panjaitan, Nashriana, \& Ikhsan, 2018).

\section{B. Sumber Data}

Sumber data yang digunakan dalam penulisan jurnal ini di peroleh pada literature, peraturan perundang-undangan, sumber referensi jurnal, artikel ilmiah dan dan kamus hokum. Berdasarkan uraian keterkaitan kasus di atas, data sekunder dibagi menjadi 3 macam, yaitu; 
a. Bahan hukum primer;

Bahan hukum primer yang digunakan dalam penulisan jurnal ini diantaranya sebagai berikut;

1) Kitab Undang-undang hukum perdata pasal 1504

2) Undang - undang nomor 8 tentang perlindungan konsumen

3) Undang - Undang Nomor 40 Tahun 2007 Tentang Perseroan Terbatas

4) Peraturan Pemerintah Peraturan Pemerintah Republik Indonesia Nomor 12 Tahun 1969 Tentang Perusahaan Perseroan Terbatas (Persero)

5) Peraturan pemerintah nomor 58. Tahun 2001 tentang pembinaan pengawasan dan penyelenggaraan perlindungan konsumen.

b. Bahan hukum sekunder

Bahan hukum sekunder yaitu bahan hukum yang terdiri atas buku, pendapat, atau dengan kata lain yaitu bahan hukum diluar dari bahan hukum primer, yaitu:

1) Kamus

2) jurnal hukum

3) buku hukum,

4) Media masa

c. Bahan hukum tersier

Bahan hukum tersier yang digunakan dalam proses penelitian ini menggunakan data yang di peroleh dari sumber primer dan sumber sekunder, yaitu:

1) Katalog Perpustakaan

2) Bilgliografi

3) Daftar bacaan

4) Ensiklopedia

Cara memperoleh data

Data diperoleh dari studi kepustakaan (library research) dengan cara menelaah buku - buku hukum yang terkait dengan permasalahan hukum perlindungan konsumen tersebut, mengkaji buku literature, dan membuat catatan yang berhubungan dengan masalah yang dikaji dan/atau diteliti. Studi kepustakaan di peroleh dari data-data yang diperoleh melalui jurnal hukum, undang-undang, dan artikel ilmiah terkait dengan kasus tersebut.

\section{Hasil dan Pembahasan}

Menurut Az Nasution iklan komersil yang berpotensi menimbulkan dampak negative di masyarakat dapat diminta pertanggung jawaban kepada para pihak yang terlilbat dalam periklanan, terutama terutama pelanggaran-pelanggaran terhadapat ketentuan yang terdapat Undang-undang perlindungan konsumen. Pertanggungjawaban yang dimaksud termasuk didalamnya pelanggaran yang menyangkut kreativitass perusahaan periklanan atau media periklanan yang bertentangan dengan asas-asas periklanan. Pelaku usaha periklanan itu terdiri atas tiga kelompok yaitu pengiklan, perusahaan iklan atau Biro Periklanan dan media (Nasution, 2014). 
Untuk mencegah dari iklan yang menyesatkan, maka di berlakukanlah Undang Undang perlindungan Konsumen. Saat ini arus globalisasi berlangsung cukup pesat, segalanya harus cepat dan efisien, para pelaku usaha berlomba untuk mendapatkan keuntungan yang besar sehingga dalam pemasaran produk tersebut menggunakan cara yang merugikan konsumen. contoh peristiwa Nissan Juke yang terjadi pada bulan maret tahun 2012 silam merupakan kasus yang menyita perhatian public. Dalam kasus tersebut di sebutkan jika produk kendaraan memiliki kecacatan pada bagian mesin, seperti laporan National Traffic Safety Administration (NHTSA) di temukan adanya pemasangan sensor regulator yang kurang kencang sesuai dengan spesifikasi yang benar akibatnya sensor regulator pada rel bahan bakar bisa mengendur apabila ada faktor panas dan akan menyebabkan kebocoran pada saluran pada bahan bakar dengan sensor regulator mengakibatkan potensi kebakaran selain sensor bahan bakar yang tidak bisa berfungsi sebagaimana mestinya saat terjadi kecelakaan Air Bag ( Kantong balon) tidak mengembang dan pintu terkunci secara otomatis sehingga korban tidak bisa cepat - cepat menyelamatkan diri keluar, sehingga Remaja tewas terpanggang di dalam mobil. Nissan Motor Corp menarik kembali produk Nissan juke di seluruh dunia terdapat 118.000 produk Nissan juke yang di Tarik, setelah badan keselamatan lalu lintas jalan raya nasional (National Highway Traffic Safety Administration/NHTSA) menemukan cacat pada bagian mesin dan pintu. Namun hingga kini kecelakaan yang merenggut remaja tersebut di tutup sebagai kecelakaan tunggal.

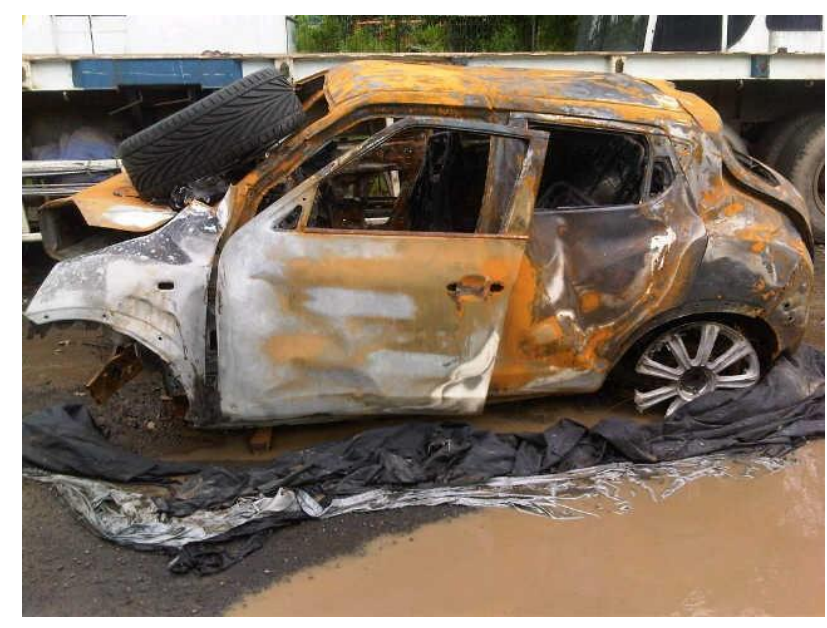

Gambar 1

Kecelakaan Nissan Juke yang menewaskan remaja putri di Jakarta

Dalam kaitannya dengan perlindungan konsumen yang berfungsi untuk menjamin kepastian hukum dan memberikan perlindungan hukum bagi konsumen, dalam kasus Nissan juke tersebut masyarakat sudah melaporkan bahwa produk tersebut bermasalah bahkan memiliki cacat pada produk mobil. Namun pihak pelaku usaha tidak menanggapinya, sedangkan pemerintah lamban dalam bertindak. 


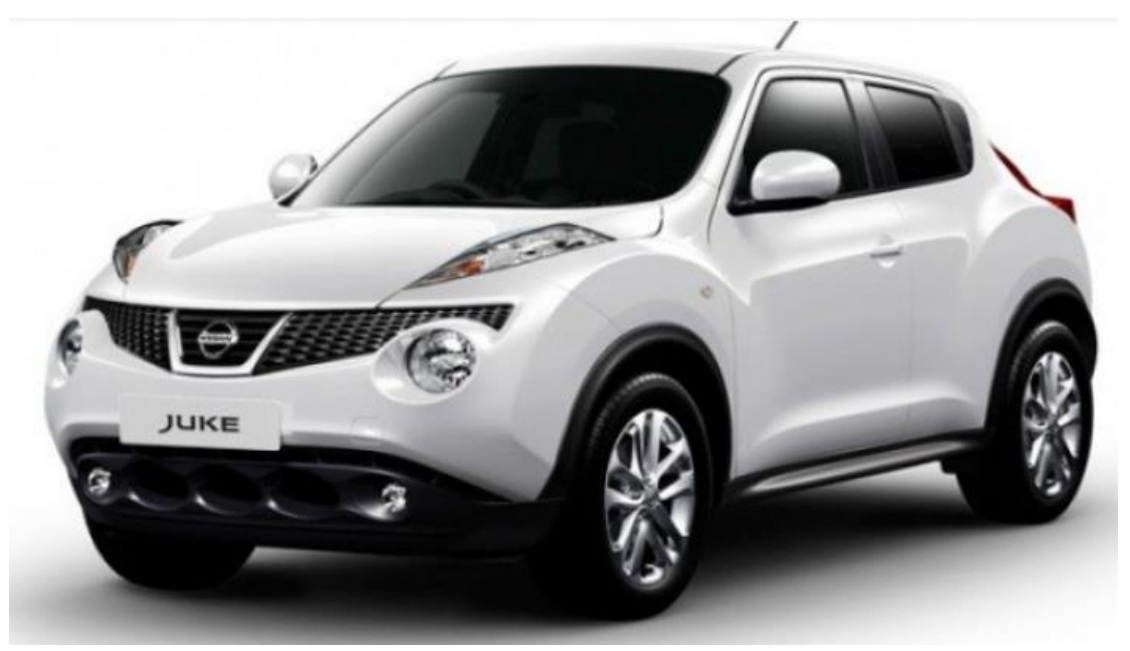

Gambar 2

Produk Nissan Juke yang di Tarik di seluruh dunia

\section{A. Sesuai dengan pasal 3 Undang-undang Perlindungan Konsumen, tujuan dari} Perlindungan Konsumen adalah;

1) Meningkatkan kesadaran, kemampuan dan kemandirian konsumen untuk melindungi diri,

2) Mengangkat harkat dan martabat konsumen dengan cara menghindarkannya dari efek negatif pemakaian barang dan/atau jasa,

3) Meningkatkan pemberdayaan konsumen dalam memilih, menentukan dan menuntut hak-haknya sebagai konsumen,

4) Menciptakan sistem perlindungan konsumen yang mengandung unsur kepastian hukum dan keterbukaan informasi serta akses untuk mendapatkan informasi,

5) Menumbuhkan kesadaran pelaku usaha mengenai pentingnya perlindungan konsumen sehingga tumbuh sikap yang jujur dan bertanggungjawab dalam berusaha,

6) Meningkatkan kualitas barang dan/atau jasa yang menjamin kelangsungan usaha produksi barang dan/atau jasa, kesehatan, kenyamanan, keamanan dan keselamatan konsumen.

\section{B. Asas Perlindungan Konsumen}

1) Asas Manfaat; mengamanatkan bahwa segala upaya dalam penyelenggaraan perlindungan konsumen harus memberikan manfaat sebesar-besarnya bagi kepentingan konsumen dan pelaku usaha secara keseluruhan,

2) Asas Keadilan; partisipasi seluruh rakyat dapat diwujudkan secara maksimal dan memberikan kesempatan kepada konsumen dan pelaku usaha untuk memperoleh haknya dan melaksanakan kewajibannya secara adil,

3) Asas Keseimbangan; memberikan keseimbangan antara kepentingan konsumen, pelaku usaha, dan pemerintah dalam arti materiil ataupun spiritual, 
4) Asas Keamanan dan Keselamatan Konsumen; memberikan jaminan atas keamanan dan keselamatan kepada konsumen dalarn penggunaan, pemakaian dan pemanfaatan barang dan/atau jasa yang dikonsumsi atau digunakan;

5) Asas Kepastian Hukum; baik pelaku usaha maupun konsumen mentaati hukum dan memperoleh keadilan dalam penyelenggaraan perlindungan konsumen, serta negara menjamin kepastian hukum.

\section{Hak-hak Konsumen Sesuai dengan Pasal 5 Undang-undang Perlindungan Konsumen, Hak-hak Konsumen adalah:}

1) Hak atas kenyamanan, keamanan dan keselamatan dalam mengkonsumsi barang dan/atau jasa;

2) Hak untuk memilih barang dan/atau jasa serta mendapatkan barang dan/atau jasa tersebut sesuai dengan nilai tukar dan kondisi serta jaminan yang dijanjikan;

3) Hak atas informasi yang benar, jelas dan jujur mengenai kondisi dan jaminan barang dan/atau jasa;

4) Hak untuk didengar pendapat dan keluhannya atas barang dan/atau jasa yang digunakan;

5) Hak untuk mendapatkan advokasi, perlindungan dan upaya penyelesaian sengketa perlindungan konsumen secara patut;

6) Hak untuk mendapat pembinaan dan pendidikan konsumen;

7) Hak untuk diperlakukan atau dilayani secara benar dan jujur serta tidak diskriminatif;

8) Hak untuk mendapatkan kompensasi, ganti rugi/penggantian, apabila barang dan/atau jasa yang diterima tidak sesuai dengan perjanjian atau tidak sebagaimana mestinya;

9) Hak-hak yang diatur dalam ketentuan peraturan perundang-undangan lainnya.

Sebagai alat pemasaran bagi konsumen, iklan memiliki dampak yang negative bagi masyarakat. Pelaku usaha akan berlomba memasarkan produk tersebut dengan menggunakan iklan, hal tersebut tidak luput juga bila pelaku usaha menggunaka iklan iklan yang menyesatkan dan merugikan konsumen, pelanggaran konsumen yang dilakukan oleh pelaku usaha belum menemukan titik terang dalam praktik (Widijowati, 2016). Dalam peredaran iklan yang menyesatkan sebenarnya telah diatur di dalam pasal 8 ayat (1) huruf f undang undang perlindungan konsumen yang di jelaskan bahwa pelaku usaha dilarang memproduksi barang yang tidak sesuai dengan label, atau pun komposisi barang tersebut atau pun iklan yang bertentangan dengan kepatutan masyarakat dalam aturan kode iklan, misalkan mengiklankan yang tidak sesuai dengan realistas produk tersebut, itu merupakan hal yang bermasalah (Herawati, 2006).

Berdasarkan pada pasal 10 Undang - Undang Perlindungan Konsumen juga mengatur pelaku usaha dilarang mengiklankan pernyataan yang tidak benar atau menyesatkan mengenai;

a. Harga atau tarif barang dan/atau jasa;

b. Kegunaan suatu barang dan/atau jasa;

c. Kondisi, tanggungan, jaminan, hak, atau ganti rugi atas suatu barang dan/atau jasa; 
d. Tawaran potongan harga dan/atau tidak langsung merendahkan barang dan/atau jasa lain;

e. Hadiah menarik yang di tawarkan;

f. Bahaya penggunaan barang dan/atau jasa;

Pasal 11 Undang - Undang Perlindungan konsumenpun juga mengatur larangan pelaku usaha dalam mengelabuhi atau menyesatkan konsumen dengan;

a. Menyatakan barang dan/atau jasa tersebut seolah - olah telah memenuhi standar mutu tertentu;

b. Menyatakan barang dan/atau jasa tersebut seolah - olah tidak mengandung cacat tersembunyi

c. Tidak berniat menjual barang yang di tawarkan melainkan dengan maksud menjual barang lain

d. Tidak menyediakan barang dalam jumlah tertentu dan/atau jumlah yang cukup dengan maksud menjual barang yang lain;

e. Tidak menyediakan jasa dalam kapasitas tertentu atau dalam jumlah cukup dengan maksud menjual jasa yang lain

f. Menaikan harga atau tarif barang dan/atau jasa sebelum melakukan obrol.

Secara garis besar iklan yang terlarang untuk beredar yaitu iklan yang bersifat menyesatkan, mengandung unsur tidak benar serta menyinggung barang dan/atau jasa lain. Selain terdapat larangn hal umum yang terdapat dalam Undang - Undang Perlindungan konsumen, larangan iklan pada barang atau jasa pada media tertentu.

\section{Tujuan Iklan bagi pelaku usaha;}

a. Memperkenalkan kepada calon konsumen tentang suatu produk, barang atau jasa. Umumnya, mengandung bahas persuasif dengan menyertakan kelebihan atau keunggulan dari produk yang di tawarkan.

b. Mempengaruhi barang dan/atau jasa yang di tawarkan.

E. Syarat - syarat iklan yang baik

a. Memiliki bahasa yang objektif, proporsional, jujur

b. Bahasa yang jelas, padat, dan mudah di pahami

c. Tidak menyinggung, menyakiti, atau merendahkan produk lain

d. Menarik perhatian banyak orang.

\section{F. Prosedur iklan menurut hukum perundang - undangan}

Berdasarkan pasal 17 ayat (1) huruf F undang - undang nomor 8 tahun 1999 tentang perlindungan konsumen pelaku usaha periklanan dilarang memproduksi iklan yang melanggar etika dan/atau ketentuan peraturan perundang - undangan mengenai periklanan. Selain memproduksi pelaku periklanan juga melarang peredaran iklan yang melanggar dengan ketentuan sebagai berikut; Pasal 1 ayat 3 Undang - Undang Perlindungan Konsumen sebagai berikut;

Pelaku usaha adalah setiap orang perseorangan atau badan usaha, baik yang berbentuk badan hukum maupun bukan badan hukum yang didirikan dan berkedudukan atau melakukan kegiatan dalam wilayah hukum Negara republik 
Indonesia, baik sendiri maupun bersama - sama melalui perjanjian menyelenggarakan kegiatan usaha dalam berbagai bidang ekonomi.

Peluang iklan yang menyesatkan di tengah masyarakat Indonesia akan berkembang dengan sangat pesat apabila masyarakatnya sendiri enggan merinci penggunaan produk tersebut, apakah produk yang di gunakan telah sesuai dan apakah pelaku usaha dapat menjual produknya secara jujur dan tidak menyembunyikan informasi menyesatkan.

\section{Kesimpulan}

Berdasarkan rumusan masalah di atas dan sesuai dengan penjabaran yang penulis jabarkan, terdapat jawaban dalam permasalahan dalam studi kasus pembuatan jurnal ini, diantaranya pentingnya edukasi kepada masyarakat terkait dengan produk yang di beli dan/atau dikonsumsi. Indonesia sebagai Negara hokum harus menjamin warganya agar terlindungi dari permasalahan kasus iklan yang menyesatkan.

Dalam studi kasus yang di maksud juga di jabarkan bahwa iklan yang menyesatkan telah mengakar sejak lama, tidak hanya dari kasus Nissan Juke dalam penyelesaian kasus ini telah di usut oleh pihak kepolisian, sehingga membuat produk Nissan Juke di Tarik di pasaran tidak hanya di Indonesia tetapi di seluruh dunia.

Dalam Undang-undang No 8 tahun 1999 telah di jabarkan mengenai perlindungan konsumen terhadap iklan yang menyesatkan, di dalam pasal-pasal ini juga telah di jabarkan tentang sanksi yang di jerat oleh pelaku usaha yang sengaja memberikan penipuan terkait produk yang di hasilkan.

Dalam menyelesaikan kasus ini hendaknya para pelaku usaha memberikan informasi yang jujur dan sesuai fakta kegunaannya pada produk tersebut, sehingga tidak terjadi lagi kesalahpahaman dalam masyarakat terkait produk yang di pergunakan. 


\section{BIBLIOGRAFI}

Firmansyah, Anang. (2020). Komunikasi Pemasaran. Pasuruan: Qiara Media. Google Scholar

Gunawan Widjaja \& Ahmad Yani. (2000). Jaminan Fidusia. Jakarta: Raja Grafindo Persada.

Herawati, Netty. (2006). Tanggung Jawab Pelaku Usaha Atas Iklan Yang Menyesatkan. Perspektif, 11(4), 380-389. Google Scholar

Nasution, Az. (2014). Hukum Perlindungan Konsumen. Jakarta: Diadit Media.

Panjaitan, Jhon Fery Gunawan, Nashriana, Nashriana, \& Ikhsan, Rd. (2018). Pemidanaan Terhadap Anak Sebagai Pelaku Pelanggaran Lalu Lintas Yang Mengakibatkan Korban Luka Berat Analisis Putusan No. 14/PID. SusAnak/2014/Pengadilan Jambi. Sriwijaya University. Google Scholar

Purhayati, Shenia. (2020). Implementasi Undang-Undang Nomor 8 Tahun 1999 Tentang Perlindungan Konsumen Terhadap Makanan Kemasan Tanpa Menyertakan Label Komposisi Kandungan. Universitas Bhayangkara. Google Scholar

Sidabalok, Janus. (2006). Hukum perlindungan konsumen di Indonesia. Bandung: Citra Aditya Bakti. Google Scholar

Simatupang, Taufik H. (2004). Aspek Hukum Periklanan dalam Perspektif Perlindungan Konsumen. Bandung: Citra Aditya Bakti. Google Scholar

Soerjono Soekanto. (2019). Pengantar Penelitian Hukum. Jakarta: UI Press. Google Scholar

Widijowati, Dijan. (2016). Peredaran Iklan yang Menyesatkan Konsumen dihubungkan dengan Hukum Perlindungan Konsumen, Pers dan Penyiaran. Ius Constitutum, 1(2). Google Scholar

\section{Copyright holder:}

Tangkas Hadi, Atik Winanti (2021)

First publication right:

Syntax Literate: Jurnal Ilmiah Indonesia

This article is licensed under:

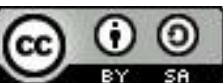

